\title{
ASSOCIATION BETWEEN EXCLUSIVE BREASTFEEDING PRACTICE, TABURIA SUPPLEMENTATION, AND STUNTING PREVALENCE AMONG CHILDREN AGED 24-60 MONTHS IN SIDOTOPO WETAN, SURABAYA
}

\author{
Firda Sahdani $^{1^{*}}$, Emyr Reisha Isaura ${ }^{1,2}$, Sri Sumarmi ${ }^{2}$ \\ ${ }^{1}$ Study Program of Nutritional Science, Department of Nutrition, Faculty of Public Health, Universitas Airlangga, Surabaya, Indonesia \\ ${ }^{2}$ Public Health Study Unit, Faculty of Public Health, Universitas Airlangga, Surabaya, Indonesia \\ *E-mail: firda.sahdani-2016@fkm.unair.ac.id
}

\begin{abstract}
Stunting is a condition in which a child's height is shorter than other children of the same age. Exclusive breastfeeding is a factor that can affect the stunting prevalence in Indonesia. In addition, specific nutritional intervention through multi-micronutrient supplementation called Taburia is given to prevent stunting. This study was aimed to determine the relationship between exclusive breastfeeding practice and taburia supplementation in children aged 24-60 months in the working area of Sidotopo Wetan Health Center, Surabaya City. This study used secondary data obtained from a child monitoring survey database from the Surabaya City Health Office in the working area of Sidotopo Wetan Health Center. The samples size was 141 children aged 24-60 month, and the statistical analysis employed was the chi-square test. The results showed that the stunting proportion was $54.60 \%$. There was a relationship between exclusive breastfeeding practice and the stunting incidence $(\mathrm{p}=0.047)$. Children who did not provide exclusive breastfeeding had a higher risk 1.97 times of stunting. Taburia supplementation also had a significant relationship with stunting incidence $(\mathrm{p}=$ 0.016). Children with non taburia had a higher risk 2.35 times of stunting. Based on these results, it can be concluded that the prevention of stunting can be overcome by maximizing exclusive breastfeeding practice and complementary foods, also the allocation of taburia.
\end{abstract}

Keywords: Stunting, exclusive breastfeeding, taburia

\section{INTRODUCTION}

In line with the condition of nutritional problems in Indonesia, one of the efforts made by the government is joining the Scaling Up Nutrition (SUN) program, which is expected to strengthen commitment and action plans to accelerate nutrition improvement (Black et al., 2013). SUN, or the National Nutrition Awareness Movement in Indonesia, is expected to reduce the chronic disease incidence in the future (Sumarmi, 2017). Stunting is one of the nutritional problems in under-five children in Indonesia. Stunting is a condition in which the child's body is shorter than other children of his age. This is a health indicator of chronically malnourished children, which provides a picture of nutrition in the past and is influenced by the environment and socioeconomics (UNICEF, 2013).

Based on the Basic Health Research (RISKESDAS) data in 2018, the stunting prevalence in Indonesia was $30.80 \%$, so this problem must be addressed immediately (Ministry of Health Republic of Indonesia, 2018). East Java is one of Indonesia's provinces with a higher stunting prevalence than the national stunting prevalence of $32.80 \%$ (Ministry of Health Republic of Indonesia, 2018). Based on the Surabaya City Health Profile in 2018, the percentage of stunted under-five children in Surabaya was $8.90 \%$. This figure has met the WHO target, but there were still areas with high stunting rates, one of which is the working area of Sidotopo Wetan Health Center. Stunting under five occurs due to the accumulated impacts of insufficient nutrient intake, poor health conditions, and inadequate care (Aridiyah et al., 2015). Parenting is an indirect factor that affects the stunting occurrence in under-five children, one of which is exclusive breastfeeding. Exclusive breastfeeding can support normal baby growth and development at 0-6 months (Ministry of Health Republic of Indonesia, 2017). This was evidenced by the research of Rizqina et al. (2019), 
which stated that there was a positive relationship between the exclusive breastfeeding history and the stunting incident in children aged 24-59 months.

The exclusive breastfeeding achievement in East Java in 2018 was $40.05 \%$ (RISKESDAS, 2018). In Surabaya, the exclusive breastfeeding proportion was $71.62 \%$, while in the working area of Sidotopo Wetan Health Center, it was $61.51 \%$ (Health Office of Surabaya City, 2019). Compared to the target by the Indonesian Ministry of Health, which is $80 \%$ (Ministry of Health Republic of Indonesia, 2017), the exclusive breastfeeding achievements in East Java, Surabaya City, and Sidotopo Wetan Health Center have not met the target.

Improvement and prevention efforts have also been made to overcome the stunting problem in Indonesia, one of which is providing specific nutritional interventions by fulfilling micronutrient intake by providing micronutrient supplementation Ministry of Health Republic of Indonesia, 2018). In overcoming micronutrient deficiencies, the Nutrition Improvement through Community Empowerment (NICE) offered multi-micronutrients comprising twelve vitamins (vitamins A, B1, B2, B3, B6, B12, D3, E, K, C, folic acid, and pantothenic acid) and four minerals (iodine, iron, zinc, and selenium) called Taburia. In Surabaya, Taburia has been disseminated in various health center working areas to handle the issue. Therefore, this study was aimed to determine the relationship between the exclusive breastfeeding history and Taburia and the stunting incidence in children aged 24-60 months.

\section{METHOD}

This study employed secondary data obtained from survey for 651 under-five childrens mentoring by the Surabaya City Health Office. The datas was provided by Sidotopo Wetan Public Health Center, Kenjeran District, Surabaya. In this study we used the datas that was collected between JanuaryFebruary 2020. Only 141 had complete data according to the research criteria. Respondents in this study were children aged 24-60 months. In this study, the inclusion criteria were respondents who filled out the survey data completely, including parental and under-five children characteristics, parenting pattern and health care. Parental Characteristics involve parental education, mother's occupation, family income, number of family member, and history of maternal disease during pregnancy. Under-five children characteristics involve age and gender. Parenting pattern and health care involve Early Initiation of Breastfeeding, under-five children caregivers, smoking family members, immunization status, integrated health post regularity, supplementary feeding for under-five children. The exclusion criteria in this study were under-five childrens who had congenital disorders or chronic diseases to minimize bias.

The exclusive breastfeeding history and Taburia supplementation became the independent variables and stunting as the dependent variable. The measurement of the exclusive breastfeeding history and taburia supplementation utilized the under-five children mentoring survey questionnaire provided by the Surabaya City Health Office in 2020 with the classification of "Yes" or "No". The exclusive breastfeeding history was the history of a child who was only given only breastmilk for at least the first six months from birth and was not given any other food or drink (including water), except medicines and vitamin or mineral drops (Ministry of Health Republic of Indonesia, 2014). Taburia was distributed at the integrated health posts in the form of nutritional sprinkles to prevent vitamin and mineral deficiencies in under-five childrens aged 6-59 months. Taburia is given to under-five childrens by adding it to the breakfast meal prepared at home (Ministry of Health Republic of Indonesia 2013). The measurement of stunting nutritional status in under-five children was done by observing the measurement results of height-for-age $<-2$ SD to $<-3$ SD (stunting) and -2 SD to 3 SD (not stunting) (Ministry of Health Republic of Indonesia, 2020).

The collected datas then was analyzed using the descriptive statistical analysis to see the frequency distribution, while the inferential statistical analysis was employed to see the relationship between variables using the chi-square test. The statistical significance was determined if the $p$-value was $\leq \alpha(0.05)$. All analyzes were carried out using SPSS version 20 software. This study has received an approval from the 
Ethics Commission of the Faculty of Dentistry, Universitas Airlangga, Surabaya, with no. 215 / HRECC.FODM / IV / 2020 on May 4, 2020.

\section{RESULTS AND DISCUSSION}

Table 1 shows the characteristics of 141 respondents, including children and parental characteristics, parenting pattern and under-five children health care. From the datas, it can be seen that most of the children $(54.60 \%)$ suffered stunting. It was known that several factors such as family income, under-five childrens' caregivers, regular visits to the integrated health post, additional food provision for under-five childrens, exclusive breastfeeding, and taburia administration showed significant relationship with stunting occurrence $(\mathrm{p}<0.05)$.

\section{Parental Characteristics}

Most of the parents, both fathers and mothers, did not graduate from high school. The majority of mothers of the under-five were not working. Mothers who did not work tended to have more time to care for and pay attention to the under-five children health and nutritional needs to support their growth and development. However, it also requires good knowledge regarding children's nutrition and health to improce children's nutritional status. Low family income, which was less than the Minimum Wage (Upah Minimum Kerja/UMK) in Surabaya (< Rp. 4,200,479.19), was found mostly in families of stunted children $(60.90 \%)$. Low economic status caused low purchasing power, so that children were vulnerable to nutritional problems due to inadequate fulfillment of dietary needs (Candra, 2013). The under-five childrens' families were mostly small families. Most of the mother with stunted children (65.52\%) was experienced the maternal disease (i.e., hypertension, diabetes, and broken amniotic fluids) during pregnancy.

\section{Under-five children Characteristics}

The age of under-five children in this study was grouped into three, namely $24-35$ months, 36-47 months, and 48-60 months. Most of the children aged 48-60 months were stunted.
Oktarina and Sudiarti (2013) stated that as the age increases, the stunting rate becomes more visible. In this study the majority children who experienced stunting were male $(60.29 \%)$. Male have a high risk of stunting because they are physically more active so that the energy reserves in the body that are used for children's growth will be reduced (Akombi et al., 2017). This result was in accordance in line with the research of Damayanti et al. (2016) who found that, stunting was more common in male children than the female children. Meanwhile, this study contradicted Aramico et al. (2016) research results, which indicated that there is no association between sex and stunting incidence. This is because there are differences in the sample criteria with this study.

\section{Under-five Children Parenting Pattern and Health Care}

Children with good parenting were more likely to have good nutritional status, while children with poor parenting tended to obtain poor nutritional status (Virdani, 2012). Table 1 presents the results of this study indicating several kinds of parenting pattern and health care for under-five childrens monitored by Sidotopo Wetan Health Center. Some of the observed variables were Early Initiation of Breastfeeding (Inisiasi Menyusu Dini/IMD), underfive children caregivers, smoking family members, immunization status, regular visits to the integrated health post, and provision of PMT.

The results indicated that most of the underfive children had received Early Initiation of Breastfeeding. Most of the under-five childrens were nurtured by the mothers themselves, and the rest of childrens were nurtured by people in addition to the mother, including grandmothers, aunts, and older siblings.

The family members of under-five childrens mostly did not smoke. Candra (2013) suggested that paternal smoking history were not proven to influence the incidence of stunting. It was possibly because the child's exposure to cigarette smoke was not too high and most of the samples were moderate smoker. In this study, the status of smoking family members in the subjects tended to be homogeneous, and the intensity was unknown. The homogeneity of the distribution of children 
Table 1. Characteristics of Families and Children

\begin{tabular}{|c|c|c|c|c|c|c|}
\hline \multirow{3}{*}{ Variable } & \multicolumn{5}{|c|}{ Nutritional Status } & \multirow{3}{*}{ p-value } \\
\hline & \multirow{2}{*}{\begin{tabular}{|c|} 
TOTAL \\
n $(\%)$
\end{tabular}} & \multicolumn{2}{|c|}{ Normal } & \multicolumn{2}{|c|}{ Stunting } & \\
\hline & & $\mathbf{n}$ & $(\%)$ & $\mathbf{n}$ & $(\%)$ & \\
\hline $\mathrm{N}$ & $141(100 \%)$ & 64 & 45.40 & 77 & 54.60 & \\
\hline \multicolumn{7}{|l|}{ Parental Characteristics } \\
\hline \multicolumn{7}{|l|}{ Father's Education } \\
\hline Graduated from high school & $61(56.7)$ & 27 & 44.26 & 34 & 55.74 & 0.814 \\
\hline Did not graduate from high school & $80(43.3)$ & 37 & 46.25 & 43 & 53.75 & \\
\hline \multicolumn{7}{|l|}{ Mother's Education } \\
\hline Graduated from high school & $56(39.7)$ & 29 & 51.79 & 27 & 48.21 & 0.216 \\
\hline Did not graduate from high school & $85(60.3)$ & 35 & 41.18 & 50 & 58.82 & \\
\hline \multicolumn{7}{|l|}{ Mother's Occupation } \\
\hline Employed & $30(21.3)$ & 17 & 56.66 & 13 & 43.34 & 0.216 \\
\hline Unemployed & $111(78.7)$ & 47 & 42.34 & 64 & 57.66 & \\
\hline \multicolumn{7}{|l|}{ Family Income } \\
\hline High ( $\geq$ UMK) & $31(22)$ & 21 & 67.74 & 10 & 32.26 & $0.005 *$ \\
\hline Low $(<\mathrm{UMK})$ & $110(78)$ & 43 & 39.09 & 67 & 60.90 & \\
\hline \multicolumn{7}{|l|}{ Number of Family Members } \\
\hline Small family ( $\leq 4$ people) & $95(67.4)$ & 38 & 40 & 57 & 60 & 0.065 \\
\hline Extended family ( $>4$ people) & $46(32.6)$ & 26 & 56.52 & 20 & 43.48 & \\
\hline \multicolumn{7}{|c|}{ History of Maternal Disease during Pregnancy ** } \\
\hline Yes & $29(20.6)$ & 10 & 34.48 & 19 & 19 & 0.186 \\
\hline No & $112(79.4)$ & 58 & 50 & 58 & 58 & \\
\hline \multicolumn{7}{|l|}{ Under-five Children Characteristics } \\
\hline \multicolumn{7}{|l|}{ Age (months) } \\
\hline $24-35$ & $48(34.0)$ & 25 & 53.20 & 23 & 48.94 & \multirow{3}{*}{0.165} \\
\hline $36-47$ & $51(36.2)$ & 25 & 49.02 & 26 & 50.98 & \\
\hline $48-60$ & $42(29.8)$ & 14 & 33.33 & 28 & 66.67 & \\
\hline \multicolumn{7}{|l|}{ Gender } \\
\hline Male & $68(48.2)$ & 27 & 39.71 & 41 & 60.29 & 0.191 \\
\hline Female & $73(51.8)$ & 37 & 50.68 & 36 & 49.32 & \\
\hline \multicolumn{7}{|l|}{ Parenting Pattern and Health Care } \\
\hline \multicolumn{7}{|l|}{ Early Initiation of Breastfeeding } \\
\hline Yes & $101(71.6)$ & 42 & 41.58 & 59 & 58.42 & 0.149 \\
\hline No & $40(28.4)$ & 22 & 55 & 18 & 45 & \\
\hline \multicolumn{7}{|l|}{ Under-five children Caregivers } \\
\hline By Mother & $115(81.6)$ & 47 & 40.87 & 68 & 59.13 & $0.023 *$ \\
\hline Other & $26(18.4)$ & 17 & 65.38 & 9 & 34.62 & \\
\hline \multicolumn{7}{|l|}{ Smoking Family Members } \\
\hline Yes & $43(30.5)$ & 20 & 46.51 & 23 & 53.49 & 0.859 \\
\hline No & $98(69.5)$ & 44 & 44.90 & 54 & 55.10 & \\
\hline Immunization Status & & & & & & \\
\hline Complete & $102(72.3)$ & 46 & 45.10 & 56 & 54.90 & 0.910 \\
\hline Incomplete & $39(27.7)$ & 18 & 46.15 & 21 & 53.85 & \\
\hline Integrated Health Post Regularity & & & & & & \\
\hline Regular & $92(65.2)$ & 36 & 39.13 & 56 & 60.87 & $0.041 *$ \\
\hline Irregular & $49(34.8)$ & 28 & 57.14 & 21 & 42.86 & \\
\hline PMT for Under-five Childrens & & & & & & \\
\hline Yes & $106(75.2)$ & 43 & 40.57 & 63 & 59.43 & $0.045^{*}$ \\
\hline No & $35(24.8)$ & 21 & 60 & 14 & 40 & \\
\hline
\end{tabular}

Note: UMK or Upah Minimum Kerja (Minimum Wage); PMT or Pemberian Makanan Tambahan (Supplementary Feeding).

**Maternal Disease History during pregnancy is defined as a history of diseases experienced during pregnancy, such as hypertension, diabetes, or rupture of membranes. *Significant p-value: $<0.05$. 
based on smoking family member status resulted in the analysis less able to show the relationship between smoking status and stunting incidence.

Most of the under-five childrens received complete immunization. Under-five children who received complete and incomplete immunization also have the same chance of stunting (Aridiyah et al., 2015). Under-five children who tended to visit the integrated health post regularly were mostly under-five childrens with stunting nutritional status $(60.87 \%)$. This was possibly because most of the under-five children in this survey were stunting. The activeness of under-five childrens being brought to the integrated health post has a huge effect on monitoring nutritional status. The use of the integrated health post services is one of the stunting determinants in under-five children (Ministry of Health Republic of Indonesia, 2011). In the integrated health post, there was also provision of supplementary feeding (Pemberian makanan tambahan/PMT) for under-five childrens. In this study, PMT was mostly administered to stunted children with a proportion of $59.43 \%$. Provision of Supplementary Food is intended as an effort to provide additional food to increase nutritional intake and to meet nutritional needs for achieving a good nutritional status (Regulation of the Minister of Health of the Republic of Indonesia Number 51 of 2016).

Table 2 shows the relationship between the exclusive breastfeeding history and taburia supplementation with the stunting incidence in children aged 24-60 months in the working area of Sidotopo Wetan Health Center. Based on the analysis results, it can be induced that the proportion of stunted children receiving exclusive breastfeeding was $48.58 \%$. This number was lower than the children with normal nutritional status $(53.42 \%)$. The percentage of stunted children who did not receive exclusive breastfeeding and nutritional status was $63.24 \%$, which was higher than the children with normal nutritional status (36.76\%\%). Similar with Handayani et al. (2019) research, children who were exclusively breastfeed were less likely to experience stunting $(52.30 \%)$. The statistical test results with the chi-square test showed a value of $p=0.047$ ( $p \leq 0.05$ ). Thus, it can be concluded that there was a relationship between the exclusive breastfeeding history and the stunting incidence in children aged 24-60 months in Sidotopo Wetan Health Center.

The reasons for the low level of exclusive breastfeeding for stunted children may be related to some mothers under five who had lack of knowledge of the importance of exclusive breastfeeding. However, we did not measure the knowledge of mothers in this study. This results was in line with the research conducted by Lestari and Dwiehesti (2020), which stated that there was a relationship between exclusive breastfeeding and the stunting incidence at Moyudan Sleman Yogyakarta Health Center, with a result of $\mathrm{p}=$ 0.000 .

Breastfeeding is no longer given to children aged $2-5$ years, which makes them prone to nutritional problems because the nutrients received by children aged 2-5 years only come from food. If the under-five children chooses foods that lack of nutritional content, there will be nutrient deficiency (Sunarti and Nugrohowati, 2014). One of the preventions to overcome the stunting issue is to provide specific nutritional interventions through the micronutrient intake fulfillment (Ministry of Health Republic of Indonesia, 2018).

A form of multi-micronutrients to prevent vitamin and mineral deficiencies in under-five children Taburia. The distribution of Taburia for children aged 24-60 months in the working area of Sidotopo Wetan Health Center can be found in Table 2, that is the proportion of under-five children received taburia supplementation was higher in stunted under-five children (62.22\%)

Table 2. Relationship between Exclusive Breastfeeding History and Taburia with Stunting Incidence

\begin{tabular}{|c|c|c|c|c|c|c|}
\hline \multirow{3}{*}{ Variable } & \multicolumn{4}{|c|}{ Nutritional Status } & \multirow{3}{*}{ p-value } & \multirow{3}{*}{ OR } \\
\hline & \multicolumn{2}{|c|}{ Normal } & \multicolumn{2}{|c|}{ Stunting } & & \\
\hline & n & $(\%)$ & n & $(\%)$ & & \\
\hline \multicolumn{7}{|c|}{ Exclusive Breastfeeding } \\
\hline No & 25 & 36.76 & 43 & 63.24 & \multirow{2}{*}{$0.047^{*}$} & \multirow{2}{*}{1,97} \\
\hline Yes & 39 & 53.42 & 34 & 46.58 & & \\
\hline \multicolumn{7}{|l|}{ Taburia } \\
\hline No & 30 & 58.82 & 21 & 41.18 & \multirow{2}{*}{$0.016^{*}$} & \multirow{2}{*}{2,35} \\
\hline Yes & 34 & 37.78 & 56 & 62.22 & & \\
\hline \multicolumn{7}{|c|}{ Exclusive Breastfeeding and Taburia } \\
\hline No & 44 & 46.32 & 51 & 53.68 & \multirow{2}{*}{0.751} & \multirow{2}{*}{1,12} \\
\hline Yes & 20 & 43.48 & 26 & 56.52 & & \\
\hline
\end{tabular}

Note: Significant $\mathrm{p}$ value: $<0,05$. 
The results demonstrated the value of $\mathrm{p}=$ $0.016(p \leq 0.05)$. Therefore, it can be concluded that there was a relationship between taburia supplementation and stunting in children aged 24-60 months. In this study, Taburia supplementation was given to children who were stunted. Micronutrient supplementation has a direct effect on increasing the HAZ index (Oktarina and Kartasurya, 2013). This results also in accordance with Chhagan et al. (2010) who stated that the supplementation of various micronutrients in stunted children had an increase in the HAZ index.

\section{CONCLUSIONS AND RECOMMENDATIONS}

In this study, it was found that there were more stunted under-five children than normal. The majority of their family income was low. Most of them were nurtured by their mothers, so that mothers have a direct role in the under-five childrens' development. Most mothers regularly brought their children to the integrated health post and received supplementary feeding. Therefore, it can be induced that family income, caregivers, integrated health post regularity visit, and supplementary feeding play a role in the stunting incidence.

This study showed a significant relationship between the exclusive breastfeeding history and the stunting incident. Therefore, the recommendation given is to maximize exclusive breastfeeding and complementary foods, and to promote taburia for under-five children. It is necessary to do a similar study by considering other factors that play a role in the stunting incidence since stunting is a multifactorial nutritional problem.

\section{REFERENCES}

Aramico, B., Sudargo,T ., \& Susilo, J. (2016). Hubungan sosial ekonomi, pola asuh, pola makan dengan stunting pada siswa sekolah dasar di Kecamatan Lut Tawar, Kabupaten Aceh Tengah. Jurnal Gizi dan Dietik Indonesia, 1(3): 121-130. Doi: 10.21927/ijnd.2013.1(3).121-130.

Aridiyah, F. O., Rohmawati, N., \& Ririanty, M. (2015). Faktor-faktor yang mempengaruhi kejadian stunting pada anak balita di wilayah pedesaan dan perkotaan (The Factors Affecting
Stunting on Under-five childrens in Rural and Urban Areas). Pustaka Kesehatan, 3(1), 163170.

Black, R. E., Alderman, H., Bhutta, Z. A., Gillespie, S., Haddad, L., Horton, S., \& Walker, S. P. (2013). Maternal and child nutrition: building momentum for impact. The Lancet, 382(9890), 372-375. doi:10.1016/S01406736(13)60988-5

Candra, A. (2013). Hubungan underlying factors dengan kejadian stunting pada anak 1-2 th. Diponegoro Journal of Nutrition and Health, 1(1), 89913.

Chhagan, M. K., Van den Broeck, J., Luabeya, K. K. A., Mpontshane, N., Tomkins, A., \& Bennish, M. L. (2010). Effect on longitudinal growth and anemia of zinc or multiple micronutrients added to vitamin A: a randomized controlled trial in children aged 6-24 months. BMC public health, 10(1), 145. doi: 10.1186/1471-2458-10-145.

Damayanti, R. A., Muniroh, L., \& Farapti, F. (2016). Perbedaan tingkat kecukupan zat gizi dan riwayat Pemberian ASI Eksklusif pada Balita Stunting dan Non Stunting. Media Gizi Indonesia, 11(1), 61-69. doi: 10.20473/mgi. v11i1.61-69

Handayani, S., Kapota, W. N., \& Oktavianto, E. (2019). Hubungan status asi eksklusif dengan kejadian stunting pada batita usia 24-36 bulan di Desa Watugajah Kabupaten Gunungkidul. Medika Respati: Jurnal Ilmiah Kesehatan, 14(4), 287-300. Doi: 10.35842/mr.v14i4.226

Health Office of Surabaya City. (2019). Profil Kesehatan Kota Surabaya Tahun 2018. Surabaya: Health Office of Surabaya City

Lestari, E. F., \& Dwihestie, L. K. (2020). ASI Eksklusif berhubungan dengan kejadian stunting pada balita. Jurnal Ilmiah Permas: Jurnal Ilmiah STIKES Kendal, 10(2), 129-136.

Ministry of Health Republic of Indonesia (2017). Pedoman Umum Pemberian Makanan Pendamping Air Susu Ibu. Jakarta : Ministry of Health Republic of Indonesia Retrieved from http://gizi.depkes.go.id/asi/pedoman\%20MPASI\%20Lokal.pdf.

Ministry of Health Republic of Indonesia (2018). Hasil Utama Riset Kesehatan Dasar 2018. Jakarta: National Agency of Health Research and Development, Ministry of Health Republic of Indonesia. Retrieved from http://www.depkes. go.id/resources/download/infoterkini/materi rakorpop_2018/Hasil\%20Riskesdas\%202018. pdf. 
Ministry of Health Republic of Indonesia (2020). Peraturan Menteri Kesehatan Republik Indonesia Nomor 2 Tahun 2020 Tentang Standar Antropometri Anak. Jakarta: Ministry of Health Republic of Indonesia

Ministry of Health Republic of Indonesia. (2011). Standar Antropometri Penilaian Status Gizi Anak. Jakarta: Direktorat Bina Gizi

Ministry of Health Republic of Indonesia. (2013). Peraturan Menteri Kesehatan Republik Indonesia Nomor 41 Tahun 2013 Tentang Standar Bubuk Tabur Gizi. Jakarta: Ministry of Health Republic of Indonesia.

Ministry of Health Republic of Indonesia. (2014). Situasi dan Analisis ASI Eksklusif. INFODATIN KEMENKES RI. Retrieved from https://www. kemkes.go.id/article/view/14010200010/ situasi-dan-analisis-asi-eksklusif.html

Oktarina, N. H., \& Kartasurya, M. I. (2013). Pengaruh pemberian micronutrient sprinkle terhadap status antropometri $\mathrm{BB} / \mathrm{U}, \mathrm{TB} / \mathrm{U}$ dan BB/TB Anak Stunting Usia 12-36 Bulan. Journal of Nutrition College, 2(1), 192-199. doi: 10.14710/jnc.v2i1.2099

Regulation of the Minister of Health of the Republic of Indonesia Number 5 of 2016. Standar Produk Suplementasi Gizi. Jakarta: Ministry of Health.
Rizqina, N., \& Zulala, N. N. (2019). Hubungan riwayat pemberian asi eksklusif dengan kejadian stunting pada balita usia 24-59 Bulan Diwilayah Kerja Puskesmas Godean I Kabupaten Sleman. [Undergraduate's Thesis]. Universitas 'Aisyiyah Yogyakarta.

Sumarmi, S. (2017). Tinjauan Kritis intervensi multi mikronutrien pada 1000 hari pertama kehidupan. Nutrition and Food Research, 40(1), 17-28. doi: 10.22435/pgm.v40i1.6374.17-28

Sunarti, S., \& Nugrohowati, A. K. (2014). Korelasi status gizi, asupan zat besi dengan kadar feritin pada anak usia 2-5 tahun di Kelurahan Semanggi Surakarta. Kes Mas: Jurnal Fakultas Kesehatan Masyarakat Universitas Ahmad Daulan, 8(1), 24946, 11-18. doi: 10.12928/ kesmas.v8i1.1037

UNICEF. (2013). Improving child nutrition, the achievable imperative for global progress. New York: United Nations Chilren's Fund

Virdani, A. S. (2012). Hubungan antara pola asuh terhadap status gizi balita usia 12-59 bulan di WilayahKerja Puskesmas KalirungkutKelurahan Kalirungkut Kota Surabaya. [Undergraduate's Thesis]. Universitas Airlangga.

World Health Organization. (2013). Childhood stunting: contex, causes, and consequencesWHO conceptual framework for stunting. Maternal and Child Nutrition 2013; 9 (Suppl 2):27-45. 